\title{
Influence of Corophium volutator and Hydrobia ulvae on intertidal benthic diatom assemblages under different nutrient and temperature regimes
}

\author{
Scot E. Hagerthey*, Emma C. Defew**, David M. Paterson \\ Sediment Ecology Research Group, Gatty Marine Laboratory, University of St. Andrews, St. Andrews, Fife KY16 8LB, \\ Scotland, UK
}

\begin{abstract}
Epipelic diatoms dominate the microphytobenthos of estuarine sediments, where they play important roles in ecological processes such as primary production, secondary production and sediment stability. Grazing (top-down control) and nutrients (bottom-up control) regulate the biomass and species composition of intertidal benthic diatom assemblages. However, observations of grazing/predation effects on species richness differ under contrasting nutrient conditions. We investigated the interactive effects of grazing, nutrients and temperature and compared the impacts of Corophium volutator and Hydrobia ulvae -2 species that differ in their feeding strategies and bioturbation effects. Diatom assemblages were collected from 2 estuaries (Biezelingsche Ham, Westerschelde, high nutrient, and Zandkreek, Oosterschelde, low nutrient) in The Netherlands that differ in their dominant macrofaunal grazer species. Assemblages were grown in the laboratory without (control) and with grazing activity under different nutrient and temperature regimes. $C$. volutator exerted a strong regulatory influence on epipelic diatoms by reducing biomass, and preferentially consuming certain dominant taxa, thereby increasing species richness, evenness and diversity. The percentage of epipsammic species increased in the presence of C. volutator, at the expense of Navicula species. Biezelingsche Ham assemblages grazed by $C$. volutator were not influenced by nutrient or temperature regime, while control assemblages were influenced by temperature. In contrast, differences in the structure of diatom assemblages between the treatments were far less pronounced for $H$. ulvaegrazed and control Zandkreek assemblages. H. ulvae appeared to be a general consumer, grazing subdominant species. Species richness was greater at low temperature, regardless of nutrient level. Macrofaunal grazing did not predictably increase or decrease species diversity, but could potentially do both, and it may mask the effects of environmental and bottom-up control.
\end{abstract}

KEY WORDS: Benthic diatoms $\cdot$ Grazing $\cdot$ Nutrients $\cdot$ Temperature $\cdot$ Corophium volutator $\cdot$ Hydrobia ulvae $\cdot$ Estuaries $\cdot$ Intertidal mudflats

\section{INTRODUCTION}

Single-celled phototrophic diatoms often dominate the microphytobenthos of intertidal estuarine sediments (Paterson \& Hagerthey 2001). Diatoms are of particular importance since they contribute signifi-

\footnotetext{
${ }^{*}$ Present address: Everglades Division, South Florida Water Management District, PO Box 24680, West Palm Beach, Florida 33416-4680, USA

${ }^{* *}$ Corresponding author. Email: ecd2@st-andrews.ac.uk
}

cantly to estuarine primary production (MacIntyre et al. 1996), with estimates ranging from 29 to $314 \mathrm{~g} \mathrm{C} \mathrm{m}^{-2}$ $\mathrm{yr}^{-1}$ (Underwood \& Kromkamp 1999). Microphytobenthos supports a large portion of estuarine secondary production (Miller et al. 1996, Page 1997) and minimizes sediment erosion through the production of extracellular polymeric substances (EPS) (Yallop et al. 1994, Paterson 1997, Austin et al. 1999). The factors that determine the abundance and distribution of diatom species in estuarine sediments are still poorly understood and the debate amongst ecologists contin- 
ues as to whether the primary control is by bottom-up (through available resources) or top-down factors (from predators) (Power 1992).

Tilman (1999) argues that ecosystem dynamics and functions are regulated by species composition, because species drive ecological processes and have individual traits. This implies that the regulatory and selective mechanisms such as competition, predation, and disturbance will affect microphytobenthic processes, including primary productivity, by regulating assemblage composition and biomass. While many studies have shown the effects of hydrodynamics (see Paterson \& Hagerthey 2001), grazing (see Miller et al. 1996), and nutrient supply (Posey et al. 1999, Wulff et al. 2000) on microphytobenthic biomass, few have addressed species composition.

There is substantial evidence indicating that benthic diatoms are the primary food resource for many macrofauna and meiofauna taxa inhabiting estuarine sediments (Page 1997, Buffan-Dubau \& Carman 2000). More importantly, some estuarine macrofauna regulate microphytobenthic biomass and production (Reise 1992, Underwood \& Paterson 1993, Smith et al. 1996). Top-down control from grazers can be considered a major perturbation to diatom assemblages on an estuarine mudflat, with the amphipod Corophium volutator (Pallas) and the gastropod Hydrobia ulvae (Pennant) being among the most common and abundant grazers. C. volutator is generally considered to be an unselective deposit feeder, although suspension feeding and epipsammic browsing may occur (Gerdol \& Hughes 1994a,b), while $H$. ulvae has been shown to rely on deposit feeding and browsing (Lopez \& Kofoed 1980, Morrisey 1988a,b, Blanchard et al. 2000). H. ulvae and C. volutator are both capable of drastically reducing natural microalgal populations (Coles 1979). In addition to their feeding strategies, infauna may affect diatom assemblage structure through sediment bioturbation. C. volutator transports sediment vertically via burrow construction and irrigation, whereas $H$. ulvae horizontally mixes the surface sediment layer (Cadée 2001).

The few studies that have directly examined the effects of grazers on microphytobenthic species richness have shown that selective grazing by macrofauna can alter species composition, with the strength of the effect differing among macrofaunal species (Reise 1992, Smith et al. 1996). The selective effects may result from differences among diatoms as a viable resource, susceptibility and survival of grazing of individual diatom taxa, as well as the size and/or hunger level of the herbivore (Steinman 1991). It is important to recognise that observations of predation effects on species richness are neither clear nor universal, and grazing impacts on diversity tend to differ under dif- ferent nutrient conditions (Proulx \& Mazumder 1998). For example, Hillebrand et al. (2000) found that the diversity of a periphyton community grazed by crustaceans and gastropods was reduced when nutrient concentrations were low, but enhanced when concentrations were high.

Both the availability of nutrients and the ambient temperature are important in determining the species composition of estuarine intertidal benthic diatom assemblages. Species composition has been linked to ammonium concentration (Peletier 1996, Underwood et al. 1998), while other macronutrients (e.g. nitrate, orthophosphate, and silicate) do not appear to be limiting to benthic diatoms (Admiraal 1977, Pinckney et al. 1995, Underwood \& Provot 2000). Seasonal succession patterns in species composition are well known (Admiraal et al. 1984, Oppenheim 1991, Underwood 1994, 1997, Saburova et al. 1995, Peletier 1996). However, many studies examine top-down and bottom-up effects as independent factors.

The objective of this laboratory study was to investigate the interactive effects of grazing, nutrients and temperature upon the biomass and composition of intertidal benthic diatom assemblages. Natural densities of Corophium volutator and Hydrobia ulvae were used in this experiment, and since these 2 macrofauna species differ in their feeding strategies and bioturbation effects, we hypothesised that their impacts on structuring diatom assemblages would differ. In addition, if intertidal diatoms have unique preferences for certain nutrient and environmental conditions, then we would expect to see structural segregation in diatom assemblages grown under different environmental conditions.

\section{MATERIALS AND METHODS}

Sediment cores were collected on 16 June 2000 from 2 intertidal mudflats whose estuaries differed in their dissolved nutrient concentrations (Table 1). The Biezelingsche Ham (B-Ham) mudflat is located on the north shore of the eutrophic Westerschelde Estuary in The Netherlands $\left(51^{\circ} 26^{\prime} \mathrm{N}, 3^{\circ} 55^{\prime} \mathrm{E}\right)$. The Zandkreek mudflat is situated on the south shore of the oligotrophic Oosterschelde Estuary in The Netherlands $\left(51^{\circ} 32^{\prime} \mathrm{N}, 3^{\circ} 54^{\prime} \mathrm{E}\right)$. Thirty-two cores (surface area $21 \mathrm{~cm}^{2}$; length $7.6 \mathrm{~cm}$ ) were collected from the upper intertidal shore of both mudflats, in regions of visibly high macrofaunal densities. Corophium volutator (68 \pm 5 ind. $\operatorname{core}^{-1} ; \mathrm{n}=3$ ) was the dominant grazer at the B-Ham mudflat, whereas Hydrobia ulvae $\left(158 \pm 20\right.$ ind. core $\left.^{-1} ; \mathrm{n}=3\right)$ dominated the Zandkreek mudflat. The experiment was terminated on 29 June 2000. 
Four tidal tanks were established in a temperaturecontrolled room $\left(15^{\circ} \mathrm{C}\right)$. Tides were synchronized with the ambient tidal cycle and corresponded to $4 \mathrm{~h}$ immersion and $8 \mathrm{~h}$ emersion periods. Tanks were illuminated for $16 \mathrm{~h} \mathrm{~d}^{-1}$ with an irradiance of $265 \pm$ $1.9 \mu \mathrm{mol} \mathrm{m} \mathrm{m}^{-2} \mathrm{~s}^{-1}$ (mean $\pm \mathrm{SE}$ ). Two natural levels of nutrient treatment were used (high and low) to assess nutrient effects. For the high-nutrient treatment, 2 tidal tanks were filled with filtered $(0.45 \mu \mathrm{m})$ water from the Westerschelde Estuary. For the low-nutrient treatment, 2 tanks were filled with filtered $(0.45 \mu \mathrm{m})$ water from the Oosterschelde Estuary. Initial and final $\mathrm{PO}_{4}, \mathrm{NO}_{3}$, $\mathrm{NO}_{2}$, and $\mathrm{NH}_{4}$ concentrations were determined using standard automated colorimetric methods (Table 1). Temperature effects were assessed using 2 treatments, high $\left(25^{\circ} \mathrm{C}\right)$ and low $\left(18^{\circ} \mathrm{C}\right)$, for each nutrient treatment. Every $4 \mathrm{~d}, 50 \%$ of the water from each tank was removed and replaced to replenish nutrients and replace loss due to evaporation. This caused an increase in salinity.

Four treatments were used to assess the impact of macrofauna on microphytobenthos, and each treatment was replicated 4 times in each of the 4 tidal tanks; thus, there were 16 cores tank ${ }^{-1}$. The treatments were (1) B-Ham cores with Corophium volutator; (2) B-Ham control cores (C. volutator removed); (3) Zandkreek cores with Hydrobia ulvae; and (4) Zandkreek control cores ( $H$. ulvae removed).

Macrofauna were removed by hand from control cores and by placing a $63 \mu \mathrm{m}$ mesh disc onto the sediment surface. The mesh facilitated the removal of grazers by driving them to the margins of the core and then onto the mesh, which allowed capture. Visual observations indicated that the majority of Corophium volutator and Hydrobia ulvae were removed within $48 \mathrm{~h}$.

To ensure that microphytobenthic species composition and biomass were similar between macrofauna and control cores at the start of the experiment, a thin sediment slurry layer (between 4 and $6 \mathrm{~mm}$ and without macrofauna and most meiofauna) from the respec- tive estuary was added to each core. The slurry consisted of algae, small sediment particles, and other organic material; it was obtained by sieving surface sediment through a $150 \mu \mathrm{m}$ mesh. Thus, sieved B-Ham sediment was added to B-Ham cores and sieved Zandkreek sediment was added to Zandkreek cores. To prevent the immigration or emigration of macrofauna, a $200 \mu \mathrm{m}$ mesh extending $5 \mathrm{~cm}$ above the top was wrapped around each core.

Microphytobenthic biomass was measured as chlorophyll a $(\mathrm{chl} a)$, minimum fluorescence $\left(F_{0}{ }^{15}\right.$; used as a biomass proxy after Honeywill et al. 2002) and cell density. Chl a was determined by HPLC (Wiltshire et al. 1998). A $5 \mathrm{~mm}$ deep sediment sub-sample was collected from each core using a syringe $(1.8 \mathrm{~cm}$ diameter). Each sub-sample was frozen in liquid nitrogen and stored at $-70^{\circ} \mathrm{C}$ until analysis. Chl a was extracted from $\sim 0.1 \mathrm{~g}$ of freeze-dried sediment using $1 \mathrm{ml}$ of dimethylformamide (90\% DMF) for $24 \mathrm{~h}$ at $4{ }^{\circ} \mathrm{C}$. The solvent was then filtered $(0.2 \mu \mathrm{m})$ and injected into an HPLC equipped with a Nucleosil C18 column and a photodiode array detector.

Minimum fluorescence measurements were made using a non-invasive pulse-amplitude-modulated (PAM) diving fluorometer (Walz). Dark-adapted measurements were made on surface biofilms after $15 \mathrm{~min}$. This length of time is considered optimal for achieving a stable value for $F_{0}{ }^{15}$ (Barranguet \& Kromkamp 2000, Perkins et al. 2001).

The composition and abundance of diatom cells from each treatment were characterised from diatoms collected using the lens tissue technique (Eaton \& Moss 1966). Acid-cleaned samples were mounted in Naphrax, and taxa were observed and identified using a Zeiss Universal Light microscope (total magnification, $1250 \times)$. Three-hundred valves per slide were counted. Cell densities were expressed as the number of valves per unit area $\left(\mathrm{cm}^{-2}\right)$.

One-way ANOVA was used to determine whether measured parameters were significantly different

Table 1. Initial and final nutrient concentrations ( $\mu$ mol $\mathrm{l}^{-1} \mathrm{~N}$ or $\mathrm{P}$ ) and molar $\mathrm{N}: \mathrm{P}$ for each of the species assemblages. Lownutrient water was collected from the Oosterschelde Estuary, whereas high-nutrient water was collected from the Westerschelde Estuary

\begin{tabular}{|c|c|c|c|c|c|c|c|c|}
\hline & \multicolumn{4}{|c|}{$\begin{array}{l}\text { Oosterschelde (Zandkreek) } \\
\text { Low nutrient }\end{array}$} & \multicolumn{4}{|c|}{$\begin{array}{c}\text { Westerschelde (Biezelingsche Ham) } \\
\text { High nutrient }\end{array}$} \\
\hline & \multicolumn{2}{|c|}{$18^{\circ} \mathrm{C}$ (low) } & \multicolumn{2}{|c|}{$25^{\circ} \mathrm{C}$ (high) } & \multicolumn{2}{|c|}{$18^{\circ} \mathrm{C}$ (low) } & \multicolumn{2}{|c|}{$25^{\circ} \mathrm{C}$ (high) } \\
\hline & Start & End & Start & End & Start & End & Start & End \\
\hline $\mathrm{NH}_{4}$ & 6.2 & 0.2 & 15.3 & 6.8 & 15.2 & 2.0 & 22.5 & 7.4 \\
\hline $\mathrm{NO}_{2}$ & 2.3 & 0.3 & 4.4 & 1.9 & 7.8 & 3.0 & 14.9 & 11.3 \\
\hline $\mathrm{NO}_{3}$ & 57 & 8.0 & 70 & 9.4 & 204 & 40 & 213 & 108 \\
\hline $\mathrm{PO}_{4}$ & 2.3 & 0.4 & 2.8 & 0.9 & 3.4 & 0.2 & 3.6 & 1.0 \\
\hline Molar N:P & 28.5 & 21.3 & 32.0 & 20.1 & 66.8 & 225 & 69.6 & 126 \\
\hline
\end{tabular}


among control and macrofaunal cores (Zar 1999). Data were log-transformed prior to analysis if this improved the homogeneity of variances. Student-Newman-Keuls (SNK) multiple range tests were used to test for significant $(p<0.05)$ differences between cell densities of grazed and control treatments. Canonical correspondence analysis (CCA) was used to assess the relationships between the relative abundances of diatom taxa and 12 environmental variables for each assemblage (i.e. B-Ham and Zandkreek). Correlations between relative abundances and environmental variables and the new canonical variable were used as the basis of interpretation. Environmental variables considered in the analysis were: macrofaunal presence or absence; chl $a_{i} F_{0}{ }^{15}$; temperature; salinity; sediment carbohydrate concentration (data not shown); final $\mathrm{PO}_{4}, \mathrm{NO}_{3}$,

Table 2. Correlations of the relative abundances of species and environmental data with canonical variables 1 (CA1) and 2 (CA2) for each diatom assemblage (Biezelingsche Ham and Zandkreek). Only species with a correlation coefficient that exceeded \pm 0.300 are shown

\begin{tabular}{|c|c|c|c|c|c|}
\hline Biezelingsche Ham & CA1 & CA2 & Zandkreek & CA1 & CA2 \\
\hline$\%$ variance explained & 25.6 & 9.4 & $\%$ variance explained & 12.9 & 9.4 \\
\hline Cumulative \% explained & 25.6 & 35.0 & Cumulative \% explained & 12.9 & 22.3 \\
\hline$F_{0}^{15}$ & -0.824 & -0.324 & Salinity & -0.443 & -0.230 \\
\hline Chl a & -0.440 & -0.203 & $\mathrm{PO}_{4}$ & -0.375 & -0.228 \\
\hline Temperature & -0.120 & -0.492 & Temperature & -0.361 & -0.148 \\
\hline $\mathrm{PO}_{4}$ & -0.119 & -0.483 & $F_{0}^{15}$ & -0.352 & 0.385 \\
\hline Salinity & -0.118 & -0.442 & $\mathrm{NH}_{3}$ & -0.253 & -0.094 \\
\hline $\mathrm{NH}_{4}$ & -0.114 & -0.517 & $\mathrm{NO}_{2}$ & 0.208 & -0.164 \\
\hline $\mathrm{NO}_{2}$ & -0.064 & -0.496 & $\mathrm{NO}_{3}$ & 0.316 & -0.139 \\
\hline $\mathrm{NO}_{3}$ & -0.044 & -0.445 & Chl a & 0.446 & 0.004 \\
\hline Molar N:P & 0.048 & -0.044 & Carbohydrates & 0.472 & 0.037 \\
\hline Carbohydrates & 0.059 & -0.313 & Hydrobia ulvae & 0.495 & -0.576 \\
\hline Corophium volutator & 0.968 & -0.302 & Molar N:P & 0.583 & 0.219 \\
\hline Navicula phyllepta & -0.746 & -0.242 & Nitzschia frustulum & -0.541 & -0.170 \\
\hline Stauroneis sp. 1 & -0.662 & -0.598 & Stauroneis sp. 1 & -0.517 & 0.461 \\
\hline Navicula rostellata & -0.646 & -0.125 & Navicula sp. 5 & -0.379 & 0.171 \\
\hline Nitzschia frustulum & -0.603 & 0.809 & Amphora sp. 2 & -0.348 & 0.378 \\
\hline Navicula digitoradiata & -0.522 & -0.205 & Navicula sp. 6 & -0.328 & 0.130 \\
\hline Pleurosigma aestuarii & -0.448 & -0.137 & Navicula sp. 11 & -0.321 & 0.128 \\
\hline Achnanthes sp. 2 & -0.350 & 0.206 & Thalassiosira decipiens & -0.318 & 0.203 \\
\hline Navicula sp. 11 & -0.326 & 0.292 & Catenela adhaerans & -0.315 & 0.064 \\
\hline Synedra ulna & -0.198 & 0.432 & Navicula cryptocephala & -0.314 & 0.126 \\
\hline Navicula gregaria & 0.303 & -0.170 & Navicula flanatica & -0.282 & 0.673 \\
\hline Plagiogramma vanheurckii & 0.341 & -0.142 & Pleurosigma aestuarii & -0.025 & 0.562 \\
\hline Achnanthes sp. 1 & 0.343 & -0.05 & Plagiotropis neovitrea & 0.205 & 0.528 \\
\hline Entomoneis paludosa & 0.347 & 0.050 & Dimeregramma minor & 0.206 & -0.207 \\
\hline Amphora sp. 1 & 0.363 & -0.026 & Cocconeis scutellum & 0.215 & -0.108 \\
\hline Cocconeis scutellum & 0.381 & -0.111 & Navicula vulpina & 0.218 & 0.541 \\
\hline Plagiotropis neovitrea & 0.390 & -0.165 & Gyrosigma macrum & 0.244 & -0.135 \\
\hline Cyclotella atomus & 0.399 & -0.094 & Cyclotella meneghiniana & 0.259 & -0.266 \\
\hline Actinoptychus senarius & 0.426 & -0.163 & Achnanthes exigua var. heterovalvata & 0.260 & -0.072 \\
\hline Cylindrotheca closterium & 0.428 & -0.177 & Opephora guenter-grassii & 0.263 & -0.190 \\
\hline Opephora guenter-grassii & 0.435 & 0.065 & Eunotogramma dubium & 0.272 & 0.077 \\
\hline Pseudostaurosira perminuta & 0.440 & -0.152 & Amphora sp. 1 & 0.273 & -0.301 \\
\hline Navicula sp. 8 & 0.460 & -0.222 & Tryblionella sp. 1 & 0.277 & -0.277 \\
\hline Cymatosira belgica & 0.532 & -0.117 & Navicula pygmaea & 0.288 & -0.238 \\
\hline Rhaphoneis amphiceros & 0.559 & -0.166 & Cyclotella atomus & 0.299 & -0.247 \\
\hline Cyclotella meneghiniana & 0.609 & -0.218 & Achnanthes sp. 2 & 0.321 & -0.054 \\
\hline Cocconeis peltoides & 0.655 & -0.238 & Opephora pacifica & 0.336 & -0.231 \\
\hline Nitzschia recta & 0.666 & -0.214 & Cocconeis peltoides & 0.395 & -0.131 \\
\hline Thalassiosira eccentrica & 0.740 & -0.256 & Amphora coffeaeformis var. acutiuscula & 0.460 & -0.227 \\
\hline Achnanthes hauckiana & 0.761 & -0.161 & Plagiogramma staurophorum & 0.495 & -0.304 \\
\hline Delphineis surirella & 0.763 & -0.194 & Nitzschia dissipata & 0.524 & -0.075 \\
\hline Paralia sulcata & 0.773 & -0.241 & Achnanthes hauckiana & 0.556 & -0.145 \\
\hline Nitzschia constricta & 0.795 & -0.232 & Nitzschia constricta & 0.596 & -0.702 \\
\hline Amphora coffeaeformis var. acutiuscula & 0.817 & -0.168 & & & \\
\hline
\end{tabular}


$\mathrm{NO}_{2}, \mathrm{NH}_{4}$ and molar $\mathrm{N}$ :P ratios. PC-ORD version 3.01 was used for CCA, species richness $(S)$, species evenness $(E)$, and diversity (Shannon Index, $H^{\prime}$ ) calculations. The SIMI similarity index (see Medlin 1983) was used to compare assemblages between treatments. SIMI produces an index between 0 ( 2 assemblages with no taxa in common) and 1 ( 2 assemblages identical in distribution and abundance), and it gives more weight to the abundant taxa.

\section{RESULTS}

\section{Nutrients}

Initial and final nutrient concentrations for each tank are shown in Table 1. The high nutrient treatment had $\mathrm{NO}_{3}$ and molar N:P ratios approximately 4 and 5 times higher than the low nutrient treatment. Concentrations of nutrients declined throughout the course of the experiment.

\section{Biezelingsche Ham assemblage}

A total of 93 diatom species were identified in the B-Ham assemblages. The 2 canonical axes accounted for 25.6 and $9.4 \%$ of the total variance, respectively (Table 2). The first canonical axis contrasts assemblages strongly influenced by Corophium volutator (indicated by a high positive correlation; $\mathrm{r}=0.968$ ) (Fig. 1, Table 2). In addition, $F_{0}{ }^{15}$ and chl $a$ were negatively correlated with the first axis, indicating that these variables tended to be higher in the absence of $C$. volutator. The second canonical axis contrasts the environmental treatments (Fig. 1, Table 2). With respect to the diatom taxa, Navicula phyllepta, Stauroneis sp. 1, Navicula rostellata, Nitzschia frustulum, and Navicula digitoradiata were negatively correlated with the first canonical axis, indicating that these taxa were not associated with $C$. volutator. In contrast, Amphora coffeaeformis var. acutiuscula, Nitzschia constricta, Paralia sulcata, Achnanthes hauckiana, Delphineis surirella, and Thalassiosira eccentrica had strong positive correlations with the first canonical axis, and thus they were associated with $C$. volutator. Only 2 taxa were correlated with the second canonical variable: Stauroneis sp. 1 was negatively associated, and $N$. frustulum was positively associated, indicating a preference for high nutrient-high temperature and low nutrient-low temperature conditions, respectively.

Chl $a$ and total cell densities did not differ significantly between Corophium volutator and control assemblages, except for the high nutrient-high temperature treatment, where chl a was 3 times greater in the control than $C$. volutator assemblage (Table 3$). F_{0}{ }^{15}$ was significantly greater in control than $C$. volutator assemblages for each nutrient-temperature treatment (Table 3).

\section{Corophium volutator effects on diatom assemblage}

There was very little similarity in assemblage structure between control and Corophium volutator assemblages (Fig. 2, Table 4). Species richness was greater for the C. volutator treatments than controls, except under low nutrient-high temperature conditions. Similar higher values were observed for evenness and diversity. The percentages of Navicula species were lower, whereas the percentages of epipsammic species were greater for the $C$. volutator treatments than the controls (Table 4). $F_{0}{ }^{15}$ of control assemblages increased under all environmental treatments, with this difference corresponding to higher proportions of motile Navicula taxa and lower proportions of epipsammic species (Tables $3 \& 4$ ). This suggests that $C$. volutator negatively affected epipelic diatom biomass and assemblage composition. The following patterns in relative abundances and cell densities were observed for each treatment combination (Table 5).

Low nutrient-low temperature-The control assemblages were dominated by Nitzschia frustulum, while the Corophium volutator assemblages lacked a dominant species. Cell densities of Achnanthes hauckiana, Delphineis surirella, Navicula gregaria and Nitzschia constricta were significantly greater in the grazed assemblage.

High nutrient-low temperature - The control assemblage were comprised primarily of Nitzschia frustulum

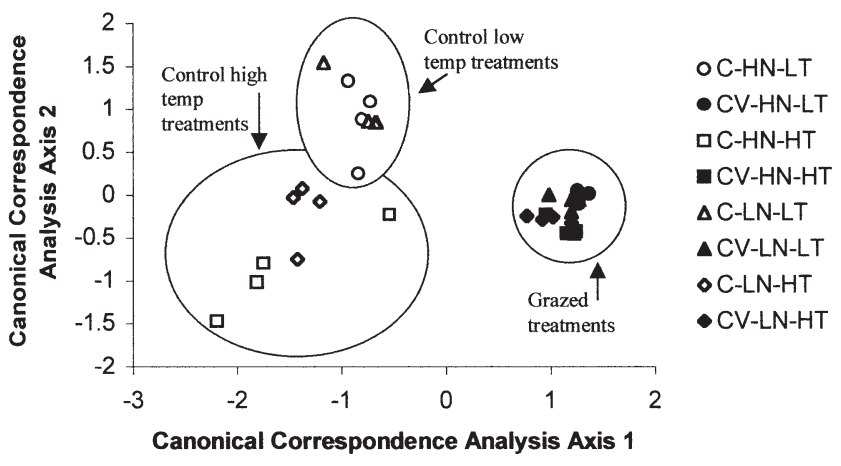

Fig. 1. Canonical correlation analysis (CCA) plot of Biezelingsche Ham diatom assemblages in the presence or absence of Corophium volutator and under different environmental conditions. Canonical variables are derived for the relative abundance of diatom taxa. C: control (no macrofauna); $\mathrm{CV}$ : with $C$. volutator; $\mathrm{HN}$ : high nutrient; $\mathrm{LN}$ : low nutrient; LT: $18^{\circ} \mathrm{C}_{i} \mathrm{HT}: 25^{\circ} \mathrm{C}$ 


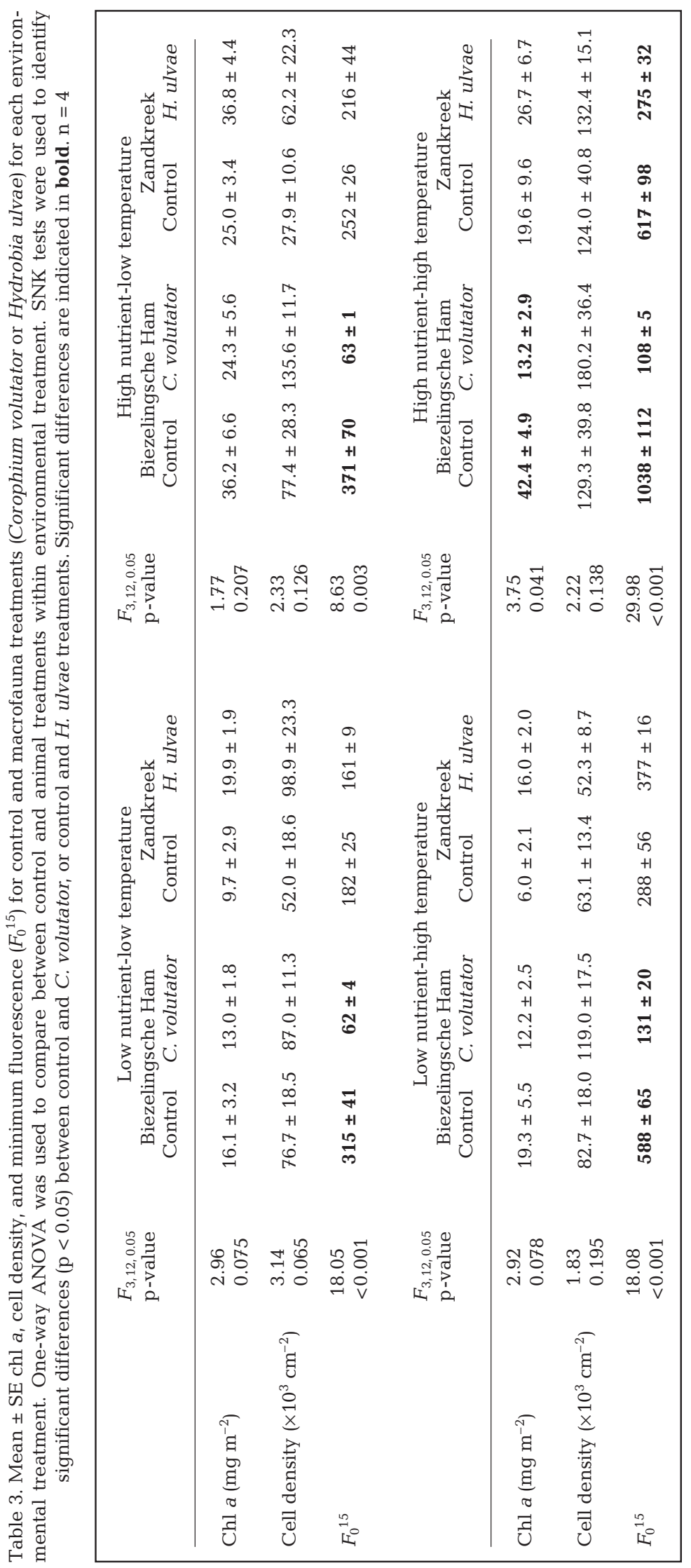

and Navicula phyllepta, although cell densities of these 2 taxa were not significantly greater than the grazed assemblages. Achnanthes hauckiana, Nitzschia constricta, and Thalassiosira eccentrica were significantly higher in the grazed assemblages.

Low nutrient-high temperature - Cell densities and relative abundances of Stauroneis sp. 1, Nitzschia frustulum, and Navicula phyllepta were significantly greater for the control assemblages. Nitzschia constricta, Navicula gregaria and Amphora coffeaeformis var. acutiuscula dominated the Corophium volutator assemblages in terms of relative abundances. However, only $N$. constricta and A. coffeaeformis var. acutiscula had significantly higher cell densities.

High nutrient-high temperature-Cell densities and relative abundances of Stauroneis sp. 1 and Navicula phyllepta were significantly higher for the control assemblages. In contrast, relative abundances of Nitzschia constricta, Achnanthes hauckiana, Amphora coffeaeformis var. acutiuscula, and Navicula gregaria were greater for the grazed assemblages, although only cell densities of $N$. constricta and $A$. coffeaeformis var. acutiuscula were significantly higher.

\section{Differences among environmental treatments}

Diatom species composition of control assemblages was strongly influenced by temperature, but not by nutrients (Fig. 1). Higher cell densities of Stauroneis sp. 1 and Navicula phyllepta, and lower densities of Nitzschia frustulum represented the major difference between the 25 and $18^{\circ} \mathrm{C}$ tanks of the control assemblages (Table 5). Salinity co-varied with temperature; thus, differences among assemblages may also be a result of salinity differences. The pooled species richness for control assemblages was greater for low-nutrient conditions, regardless of temperature, and greater for low-temperature conditions, regardless of nutrient treatment. Species evenness and diversity of control assemblages were not affected by the environmental treatments (Table 4). Taxa associated with final nitrate concentrations $>40 \mu \mathrm{mol} \mathrm{l}^{-1}\left(18^{\circ} \mathrm{C}\right)$ were Entomoneis paludosa, Navicula gregaria, and Nitzschia dissipata, and taxa associated with nitrate 
concentrations $>100 \mu \mathrm{mol}^{-1}\left(25^{\circ} \mathrm{C}\right)$ were E. paludosa, N. gregaria, Navicula flanatica, N. phyllepta, Navicula rostellata, Pleurosigma aestuarii, and Stauroneis sp. 1.

Among the nutrient and temperature treatments, Corophium volutator assemblages had a high degree of similarity, species richness, evenness and diversity
(Table 4, Figs. 1 \& 2). Cell densities of Amphora coffeaeformis var. acutiscula and Nitzschia constricta were greater for the high-temperature treatment, while cell densities of Achnanthes hauckiana and $N$. constricta were greater when nutrients were high (Table 5).

Table 4. Species richness, evenness, and diversity values for control and macrofauna treatments (Corophium volutator or Hydrobia ulvae) for each environmental treatment. Values are pooled among the 4 replicates per treatment. The relative abundances $(\%)$ of naviculoid and epipsammic taxa are also given

\begin{tabular}{|c|c|c|c|c|c|c|c|c|}
\hline & \multicolumn{4}{|c|}{ Low nutrient-low temperature } & \multicolumn{4}{|c|}{ High nutrient-low temperature } \\
\hline & \multicolumn{2}{|c|}{ Biezelingsche Ham } & \multicolumn{2}{|c|}{ Zandkreek } & \multicolumn{2}{|c|}{ Biezelingsche Ham } & \multicolumn{2}{|c|}{ Zandkreek } \\
\hline & Control & C. volutator & Control & H. ulvae & Control & C. volutator & Control & H. ulvae \\
\hline Richness $(S)$ & 54 & 57 & 53 & 52 & 47 & 51 & 56 & 52 \\
\hline Evenness $(E)$ & 0.61 & 0.79 & 0.58 & 0.70 & 0.61 & 0.76 & 0.76 & 0.74 \\
\hline Diversity $\left(H^{\prime}\right)$ & 2.45 & 3.14 & 2.29 & 2.75 & 2.4 & 3.0 & 3.04 & 2.94 \\
\hline Navicula (\%) & 25.4 & 20.2 & 23.1 & 29.4 & 29.7 & 12.4 & 41.1 & 27.1 \\
\hline \multirow[t]{4}{*}{ Epipsammic (\%) } & 16.6 & 28.2 & 14.0 & 24.1 & 9.7 & 36.1 & 15.5 & 32.2 \\
\hline & \multicolumn{4}{|c|}{ Low nutrient-high temperature } & \multicolumn{4}{|c|}{ High nutrient-high temperature } \\
\hline & \multicolumn{2}{|c|}{ Biezelingsche Ham } & \multicolumn{2}{|c|}{ Zandkreek } & \multicolumn{2}{|c|}{ Biezelingsche Ham } & \multicolumn{2}{|c|}{ Zandkreek } \\
\hline & Control & C. volutator & Control & H. ulvae & Control & C. volutator & Control & H. ulvae \\
\hline Richness $(S)$ & 48 & 43 & 46 & 54 & 38 & 55 & 47 & 49 \\
\hline Evenness $(E)$ & 0.61 & 0.76 & 0.64 & 0.60 & 0.57 & 0.72 & 0.68 & 0.58 \\
\hline Diversity $\left(H^{\prime}\right)$ & 2.34 & 2.85 & 2.44 & 2.40 & 2.07 & 2.88 & 2.63 & 2.24 \\
\hline Navicula (\%) & 36.5 & 23.2 & 40.2 & 26.8 & 44.5 & 29.4 & 33.4 & 33.4 \\
\hline Epipsammic (\%) & 9.9 & 32.5 & 9.4 & 12.6 & 4.2 & 34.4 & 12.4 & 12.4 \\
\hline
\end{tabular}

Table 5. Mean \pm SE cell densities $\left(\times 10^{3} \mathrm{~cm}^{-2}\right)$ and relative abundances (\%) for selected diatom species for control and Corophium volutator assemblages, under each environmental treatment. np: not present

\begin{tabular}{|c|c|c|c|c|c|c|c|c|}
\hline & \multicolumn{2}{|c|}{$\begin{array}{l}\text { Low nutrient- } \\
\text { low temperature }\end{array}$} & \multicolumn{2}{|c|}{$\begin{array}{l}\text { Low nutrient- } \\
\text { high temperature }\end{array}$} & \multicolumn{2}{|c|}{$\begin{array}{l}\text { High nutrient- } \\
\text { low temperature }\end{array}$} & \multicolumn{2}{|c|}{$\begin{array}{c}\text { High nutrient- } \\
\text { high temperature }\end{array}$} \\
\hline & Control & C. volutator & Control & C. volutator & Control & C. volutator & Control & C. volutator \\
\hline Achnanthes hauckiana & $\begin{array}{l}3.4 \pm 0.8 \\
5 \%\end{array}$ & $\begin{array}{c}10.3 \pm 0.8 \\
12 \%\end{array}$ & $\begin{array}{c}2.4 \pm 0.6 \\
3 \%\end{array}$ & $\begin{array}{c}7.4 \pm 1.6 \\
6 \%\end{array}$ & $\begin{array}{l}2.1 \pm 0.7 \\
3 \%\end{array}$ & $\begin{array}{l}22.2 \pm 2.4 \\
17 \%\end{array}$ & $\begin{array}{c}1.0 \pm 0.3 \\
1 \%\end{array}$ & $\begin{array}{l}14.9 \pm 1.4 \\
9 \%\end{array}$ \\
\hline $\begin{array}{l}\text { Amphora coffeaeformis var. } \\
\text { acutiscula }\end{array}$ & $\begin{array}{c}1.0 \pm 0.6 \\
1 \%\end{array}$ & $\begin{array}{c}5.2 \pm 0.3 \\
6 \%\end{array}$ & $\begin{array}{l}0.06 \pm 0.06 \\
\quad<1 \%\end{array}$ & $\begin{array}{c}11.2 \pm 2.5 \\
9 \%\end{array}$ & $\begin{array}{l}0.6 \pm 0.4 \\
\quad<1 \%\end{array}$ & $\begin{array}{c}7.3 \pm 0.5 \\
6 \%\end{array}$ & $\begin{array}{l}0.05 \pm 0.05 \\
\quad<1 \%\end{array}$ & $\begin{array}{c}17.5 \pm 6.1 \\
10 \%\end{array}$ \\
\hline Delpheneis surirella & $\begin{array}{l}0.3 \pm 0.2 \\
\quad<1 \%\end{array}$ & $\begin{array}{c}5.1 \pm 1.6 \\
6 \%\end{array}$ & $\begin{array}{l}0.2 \pm 0.2 \\
\quad<1 \%\end{array}$ & $\begin{array}{c}4.1 \pm 0.8 \\
4 \%\end{array}$ & $\begin{array}{c}0.7 \pm 0.6 \\
1 \%\end{array}$ & $\begin{array}{c}8.9 \pm 2.2 \\
6 \%\end{array}$ & $\begin{array}{l}0.2 \pm 0.2 \\
\quad<1 \%\end{array}$ & $\begin{array}{c}4.7 \pm 0.7 \\
3 \%\end{array}$ \\
\hline Navicula gregaria & $\begin{array}{l}2.7 \pm 1.1 \\
4 \%\end{array}$ & $\begin{array}{c}7.4 \pm 1.1 \\
9 \%\end{array}$ & $\begin{array}{l}4.6 \pm 2.0 \\
5 \%\end{array}$ & $\begin{array}{c}13.8 \pm 3.5 \\
13 \%\end{array}$ & $\begin{array}{l}3.5 \pm 1.6 \\
6 \%\end{array}$ & $\begin{array}{c}7.7 \pm 2.4 \\
6 \%\end{array}$ & $\begin{array}{l}9.9 \pm 3.9 \\
11 \%\end{array}$ & $\begin{array}{c}16.2 \pm 2.0 \\
10 \%\end{array}$ \\
\hline Navicula phyllepta & $\begin{array}{l}6.2 \pm 2.3 \\
9 \%\end{array}$ & $\begin{array}{c}2.2 \pm 0.6 \\
3 \%\end{array}$ & $\begin{array}{c}18.6 \pm 4.9 \\
21 \%\end{array}$ & $\begin{array}{c}3.2 \pm 0.7 \\
3 \%\end{array}$ & $\begin{array}{l}6.4 \pm 3.0 \\
11 \%\end{array}$ & $\begin{array}{c}1.8 \pm 0.5 \\
1 \%\end{array}$ & $\begin{array}{c}34.8 \pm 14.4 \\
23 \%\end{array}$ & $\begin{array}{c}3.0 \pm 0.9 \\
2 \%\end{array}$ \\
\hline Nitzschia constricta & $\begin{array}{l}0.3 \pm 0.2 \\
\quad<1 \%\end{array}$ & $\begin{array}{c}11.1 \pm 1.5 \\
13 \%\end{array}$ & $\begin{array}{l}0.6 \pm 0.2 \\
\quad<1 \%\end{array}$ & $\begin{array}{c}28.0 \pm 7.6 \\
23 \%\end{array}$ & $\begin{array}{c}1.0 \pm 0.7 \\
1 \%\end{array}$ & $\begin{array}{c}15.2 \pm 1.8 \\
11 \%\end{array}$ & $\begin{array}{c}1.2 \pm 0.2 \\
1 \%\end{array}$ & $\begin{array}{c}51.9 \pm 18.1 \\
26 \%\end{array}$ \\
\hline Nitzschia frustulum & $\begin{array}{c}39.5 \pm 18.1 \\
45 \%\end{array}$ & $\begin{array}{c}0.6 \pm 0.2 \\
<1 \%\end{array}$ & $\begin{array}{c}17.2 \pm 6.5 \\
23 \%\end{array}$ & $\begin{array}{c}2.8 \pm 0.6 \\
2 \%\end{array}$ & $\begin{array}{c}41.8 \pm 23.6 \\
45 \%\end{array}$ & $\begin{array}{c}1.3 \pm 0.5 \\
<1 \%\end{array}$ & $\begin{array}{c}11.5 \pm 5.5 \\
8 \%\end{array}$ & $\begin{array}{c}1.9 \pm 0.7 \\
<1 \%\end{array}$ \\
\hline Stauroneis sp. 1 & $\begin{array}{c}0.2 \pm 0.01 \\
1 \%\end{array}$ & $\mathrm{np}$ & $\begin{array}{c}20.0 \pm 6.5 \\
24 \%\end{array}$ & $\mathrm{np}$ & $\begin{array}{l}0.3 \pm 0.1 \\
\quad<1 \%\end{array}$ & $\mathrm{np}$ & $\begin{array}{c}49.7 \pm 16.6 \\
37 \%\end{array}$ & $\begin{array}{c}0.2 \pm 0.2 \\
<1 \%\end{array}$ \\
\hline Thalassiosira eccentrica & $\begin{array}{l}0.3 \pm 0.1 \\
\quad<1 \%\end{array}$ & $\begin{array}{c}7.4 \pm 1.5 \\
9 \%\end{array}$ & $\mathrm{np}$ & $\begin{array}{c}4.1 \pm 2.6 \\
3 \%\end{array}$ & $\begin{array}{l}0.2 \pm 0.1 \\
\quad<1 \%\end{array}$ & $\begin{array}{c}13.3 \pm 1.0 \\
10 \%\end{array}$ & $\mathrm{np}$ & $\begin{array}{c}5.3 \pm 2.7 \\
3 \%\end{array}$ \\
\hline
\end{tabular}




\section{Zandkreek assemblage}

A total of 85 benthic diatom species were identified in the Zandkreek assemblages. SIMI index values ranged between 0.63 and 0.96, indicating a high degree of similarity between diatom assemblages for control and Hydrobia ulvae treatments (Fig. 2). This similarity was mirrored in the CCA, in which the first 2 canonical axes accounted for 12.9 and $9.4 \%$ of the total variance, respectively (Table 2). The first canonical axis was negatively correlated with salinity and positively correlated with molar $\mathrm{N}: \mathrm{P}$, suggesting a nutrient and temperature effect. $H$. ulvae was negatively and $F_{0}{ }^{15}$ was positively correlated with the second canonical axis. Nitzschia frustulum and Stauroneis sp. 1 were negatively correlated with the first canonical axis, while Nitzschia constricta, Achnanthes hauckiana, and Nitzschia dissipata were positively correlated with the first canonical axis, suggesting preferential differences in salinity tolerances and nutrient requirements. $N$. constricta was negatively correlated, whereas Navicula flanatica, Pleurosigma aestuarii, and Plagiotropis neovitrea were positively correlated with the second canonical axis, indicating a weak grazing effect.

Benthic algal biomass measured as chl $a, F_{0}{ }^{15}$, and cell densities did not differ significantly between Hydrobia ulvae and control treatments, except for the high nutrient-high temperature treatment, where $F_{0}{ }^{15}$ was approximately 2.3 times greater in the control than $H$. ulvae treatment (Table 3). Compared to B-Ham control assemblages, the surface biofilm $\left(F_{0}{ }^{15}\right)$ in Zandkreek control assemblages was not as substantial (Table 3), with the exception again being the high nutrient-high temperature tank, where high densities of Navicula phyllepta and Stauroneis sp. 1 maintained a surface biofilm.

\section{Hydrobia ulvae effects on diatom assemblage}

There was a high degree of similarity between diatom assemblages grown in the presence and absence of Hydrobia ulvae, in both the type and proportion of diatom species present, regardless of environmental treatment (Figs. 2 \& 3). Within each environmental treatment, the presence of $H$. ulvae did not have a significant effect on species richness, diversity, evenness, the percentage of Navicula species, or percentage of epipsammic species present (Table 4). The following patterns in the relative abundances and cell densities were observed for each treatment combination (Table 6):

Low nutrient-low temperature-Nitzschia frustulum cell densities were similar between treatments, but the relative abundance of $N$. frustulum in the control as-

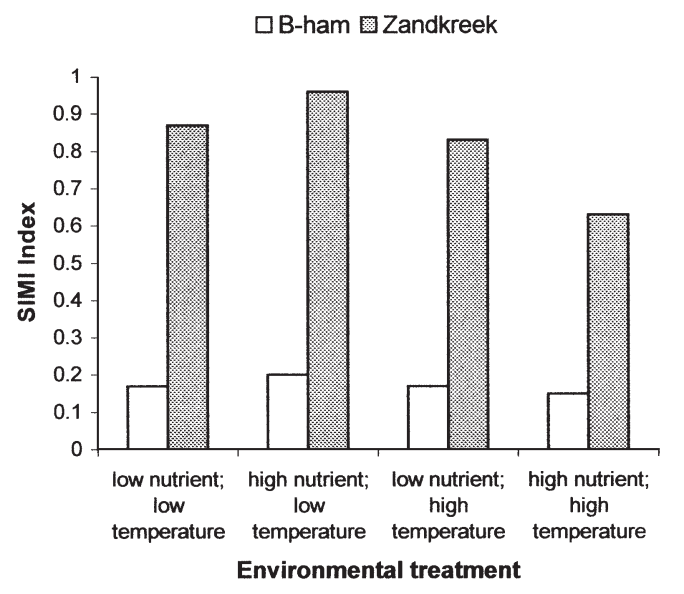

Fig. 2. SIMI similarity indices comparing control and grazed assemblages under the 4 environmental treatments. An index of 0 means the samples have no taxa in common, and an index of 1 means the samples have the same taxa and relative abundance

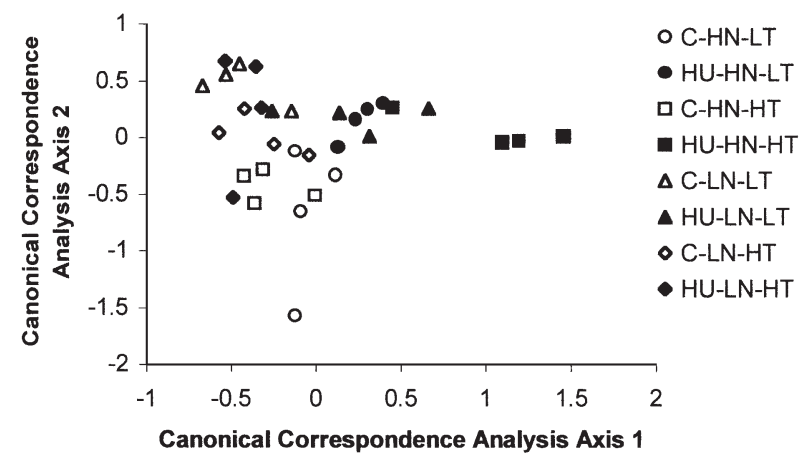

Fig. 3. CCA plot of Zandkreek diatom assemblages in the presence or absence of Hydrobia ulvae and under different environmental conditions. Canonical variables are derived for the relative abundance of diatom taxa. HU: with $H$. ulvae; other abbreviations as in Fig. 1

semblages was double that in the $H$. ulvae assemblages. Achnanthes hauckiana, Navicula gregaria, Nitzschia dissipata, Navicula phyllepta and Nitzschia constricta were dominant species in the $H$. ulvae assemblages, but only cell densities of only A. hauckiana, $N$. gregaria, and $N$. dissipata were significantly greater.

High nutrient-low temperature-Achnanthes hauckiana, Navicula gregaria, Navicula phyllepta, Nitzschia constricta, and Nitzschia frustulum were the dominant species in both assemblages, having relative abundances greater than $10 \%$. Cell densities of these taxa did not differ significantly between treatments, with the exception of A. hauckiana. Cell densities of Cocconeis peltoides and Opephora guenter-grassii were significantly greater, and cell densities of Rhaphoneis amphiceros and Stauroneis sp. 1 were significantly less for the Hydrobia 
ulvae treatment, although in general, these taxa comprised less than $2 \%$ of the total relative abundance.

Low nutrient-high temperature-Nitzschia frustulum was the dominant species of the control and Hydrobia ulvae assemblages. Navicula gregaria, Navicula phyllepta, and Stauroneis sp. 1 also made up a significant proportion of the relative abundances $(>10 \%)$ of both assemblages, and they had similar cell densities. The proportion of Stauroneis sp. 1 was greater in the presence of $H$. ulvae.

High nutrient-high temperature-Nitzschia constricta dominated the Hydrobia ulvae assemblage, where cell densities were 20 times greater than controls. Cell densities of Stauroneis sp. 1 were 2 orders of magnitude greater for the control than $H$. ulvae assemblage. Achnanthes hauckiana, Navicula gregaria, Navicula phyllepta, and Nitzschia frustulum had high relative abundances $(>10 \%)$ in both assemblages, but the cell densities of these taxa did not differ significantly between the control and $H$. ulvae assemblages.

\section{Differences among environmental treatments}

Zandkreek diatom assemblages were weakly influenced by nutrients (Fig. 3). In general, high Nitzschia frustulum densities were associated with low-nutrient conditions. Species richness of control assemblages was greater at the lower temperature than at the higher one, regardless of nutrient treatment (Table 4). However, the species evenness and diversity of control assemblages did not follow a temperature or nutrient pattern (Table 4). Species evenness and diversity of Hydrobia ulvae assemblages was lowest for the hightemperature treatments, and species richness was similar between nutrient treatments (Table 4).

\section{DISCUSSION}

Three interacting factors regulate the structure of intertidal microphytobenthic communities (i.e. the species present and their abundance). These are bottom-up, top-down, and disturbance events. Here we examined the interactions between bottom-up and top-down factors and their effects on the structure of intertidal diatoms assemblages. The results imply that top-down effects (i.e. direct consumption of microalgae or bioturbation) are predator (grazer) specific and differ in the degree to which they change the biotic and abiotic characteristics of the ecosystem. Additionally, bottom-up effects vary depending on the strength of top-down factors.

It has been suggested that most of the grazing pressure on diatom is directed towards the larger epipelon, while the small-sized epipsammon are less affected

Table 6. Mean \pm SE cell densities $\left(\times 10^{3} \mathrm{~cm}^{-2}\right)$ and relative abundances $(\%)$ for selected diatom species for control and Hydrobia ulvae assemblages, under each environmental treatment. np: not present

\begin{tabular}{|c|c|c|c|c|c|c|c|c|}
\hline & \multicolumn{2}{|c|}{$\begin{array}{l}\text { Low nutrient- } \\
\text { low temperature }\end{array}$} & \multicolumn{2}{|c|}{$\begin{array}{l}\text { Low nutrient- } \\
\text { high temperature }\end{array}$} & \multicolumn{2}{|c|}{$\begin{array}{l}\text { High nutrient- } \\
\text { low temperature }\end{array}$} & \multicolumn{2}{|c|}{$\begin{array}{l}\text { High nutrient- } \\
\text { high temperature }\end{array}$} \\
\hline & Control & H. ulvae & Control & H. ulvae & Control & H. ulvae & Control & H. ulvae \\
\hline Achnanthes hauckiana & $\begin{array}{c}1.3 \pm 0.3 \\
3 \%\end{array}$ & $\begin{array}{c}9.4 \pm 2.0 \\
10 \%\end{array}$ & $\begin{array}{c}1.1 \pm 0.8 \\
4 \%\end{array}$ & $\begin{array}{c}1.7 \pm 0.5 \\
2 \%\end{array}$ & $\begin{array}{c}1.6 \pm 0.9 \\
6 \%\end{array}$ & $\begin{array}{c}7.4 \pm 2.2 \\
14 \%\end{array}$ & $\begin{array}{c}12.5 \pm 1093 \\
6 \%\end{array}$ & $\begin{array}{c}9.5 \pm 4.6 \\
7 \%\end{array}$ \\
\hline Cocconeis peltoides & $\begin{array}{l}0.4 \pm 0.3 \\
\quad<1 \%\end{array}$ & $\begin{array}{l}0.6 \pm 0.2 \\
<1 \%\end{array}$ & $\begin{array}{l}0.3 \pm 0.1 \\
<1 \%\end{array}$ & $\begin{array}{c}0.3 \pm 0.2 \\
<1 \%\end{array}$ & $\begin{array}{c}0.5 \pm 0.3 \\
2 \%\end{array}$ & $\begin{array}{c}1.6 \pm 0.6 \\
3 \%\end{array}$ & $\begin{array}{c}0.04 \pm 0.04 \\
<1 \%\end{array}$ & $\begin{array}{l}0.4 \pm 0.1 \\
\quad<1 \%\end{array}$ \\
\hline Navicula gregaria & $\begin{array}{c}1.9 \pm 0.4 \\
5 \%\end{array}$ & $\begin{array}{c}13.0 \pm 4.0 \\
13 \%\end{array}$ & $\begin{array}{c}8.0 \pm 1.7 \\
14 \%\end{array}$ & $\begin{array}{c}4.5 \pm 1.9 \\
9 \%\end{array}$ & $\begin{array}{c}3.2 \pm 1.0 \\
12 \%\end{array}$ & $\begin{array}{c}3.8 \pm 1.6 \\
6 \%\end{array}$ & $\begin{array}{c}12.0 \pm 4.6 \\
15 \%\end{array}$ & $\begin{array}{c}21.9 \pm 2.3 \\
18 \%\end{array}$ \\
\hline Navicula phyllepta & $\begin{array}{c}4.0 \pm 1.1 \\
9 \%\end{array}$ & $\begin{array}{c}11.2 \pm 3.8 \\
10 \%\end{array}$ & $\begin{array}{c}9.9 \pm 3.7 \\
14 \%\end{array}$ & $\begin{array}{l}5.5 \pm 1.7 \\
11 \%\end{array}$ & $\begin{array}{c}3.8 \pm 1.5 \\
14 \%\end{array}$ & $\begin{array}{c}8.8 \pm 3.7 \\
14 \%\end{array}$ & $\begin{array}{c}31.5 \pm 15.6 \\
21 \%\end{array}$ & $\begin{array}{c}16.0 \pm 4.6 \\
12 \%\end{array}$ \\
\hline Nitzschia constricta & $\begin{array}{c}0.7 \pm 0.4 \\
1 \%\end{array}$ & $\begin{array}{c}7.4 \pm 3.8 \\
7 \%\end{array}$ & $\begin{array}{c}1.7 \pm 1.0 \\
3 \%\end{array}$ & $\begin{array}{c}0.9 \pm 0.3 \\
2 \%\end{array}$ & $\begin{array}{c}1.0 \pm 0.3 \\
4 \%\end{array}$ & $\begin{array}{c}3.1 \pm 1.8 \\
4 \%\end{array}$ & $\begin{array}{c}2.3 \pm 0.9 \\
2 \%\end{array}$ & $\begin{array}{c}40.3 \pm 5.4 \\
31 \%\end{array}$ \\
\hline Nitzschia dissipata & $\begin{array}{c}0.09 \pm 0.09 \\
<1 \%\end{array}$ & $\begin{array}{c}2.3 \pm 1.1 \\
4 \%\end{array}$ & $\begin{array}{c}0.03 \pm 0.03 \\
<1 \%\end{array}$ & $\begin{array}{l}0.3 \pm 0.1 \\
<1 \%\end{array}$ & $\begin{array}{l}0.1 \pm 0.1 \\
\quad<1 \%\end{array}$ & $\begin{array}{c}4.9 \pm 1.6 \\
6 \%\end{array}$ & $\begin{array}{c}1.0 \pm 0.9 \\
<1 \%\end{array}$ & $\begin{array}{l}0.6 \pm 0.3 \\
<1 \%\end{array}$ \\
\hline Nitzchia frustulum & $\begin{array}{c}28.9 \pm 12.2 \\
50 \%\end{array}$ & $\begin{array}{c}26.7 \pm 11.1 \\
26 \%\end{array}$ & $\begin{array}{c}20.6 \pm 7.1 \\
34 \%\end{array}$ & $\begin{array}{l}22.7 \pm 10.3 \\
41 \%\end{array}$ & $\begin{array}{c}5.2 \pm 3.4 \\
16 \%\end{array}$ & $\begin{array}{c}10.5 \pm 4.0 \\
17 \%\end{array}$ & $\begin{array}{c}16.9 \pm 7.0 \\
14 \%\end{array}$ & $\begin{array}{c}23.0 \pm 8.8 \\
17 \%\end{array}$ \\
\hline Opephora guenter-grassii & $\begin{array}{c}1.6 \pm 1.2 \\
2 \%\end{array}$ & $\begin{array}{c}2.5 \pm 1.6 \\
4 \%\end{array}$ & $\begin{array}{c}1.0 \pm 0.4 \\
2 \%\end{array}$ & $\begin{array}{c}1.3 \pm 0.7 \\
3 \%\end{array}$ & $\begin{array}{c}0.03 \pm 0.03 \\
\quad<1 \%\end{array}$ & $\begin{array}{c}4.6 \pm 3.2 \\
6 \%\end{array}$ & $\begin{array}{c}0.9 \pm 0.6 \\
<1 \%\end{array}$ & $\begin{array}{l}1.2 \pm 1.0 \\
<1 \%\end{array}$ \\
\hline Rhaphoneis amphiceros & $\begin{array}{c}0.05 \pm 0.05 \\
<1 \%\end{array}$ & $\begin{array}{c}0.8 \pm 0.5 \\
<1 \%\end{array}$ & $\begin{array}{c}0.04 \pm 0.04 \\
<1 \%\end{array}$ & $\begin{array}{c}0.06 \pm 0.06 \\
<1 \%\end{array}$ & $\begin{array}{c}0.3 \pm 0.1 \\
1 \%\end{array}$ & $\begin{array}{c}0.1 \pm 0.1 \\
<1 \%\end{array}$ & $\begin{array}{c}0.3 \pm 0.2 \\
\quad<1 \%\end{array}$ & $\begin{array}{c}0.4 \pm 0.2 \\
<1 \%\end{array}$ \\
\hline Stauroneis sp. 1 & $\begin{array}{l}0.1 \pm 0.04 \\
\quad<1 \%\end{array}$ & $\begin{array}{l}0.1 \pm 0.1 \\
\quad<1 \%\end{array}$ & $\begin{array}{c}2.5 \pm 0.7 \\
4 \%\end{array}$ & $\begin{array}{c}4.8 \pm 3.5 \\
10 \%\end{array}$ & $\begin{array}{c}0.4 \pm 0.2 \\
2 \%\end{array}$ & $\mathrm{np}$ & $\begin{array}{c}17.0 \pm 8.1 \\
12 \%\end{array}$ & $\begin{array}{l}0.2 \pm 0.1 \\
\quad<1 \%\end{array}$ \\
\hline
\end{tabular}


(Reise 1992). Grazing pressure should, therefore, increase the percentage composition of epipsammic species. Our results support this hypothesis, with the epipsammic fraction either increasing or occasionally remaining the same in the presence of grazers.

In the absence of grazing, competition for nutrients between species generally reduces diversity (Begon et al. 1990). For example, McClatchie et al. (1982) found that grazer exclusion decreased the number of species in a mudflat diatom assemblage. Grazer removal from B-Ham sediments decreased diversity and species richness under all environmental conditions, except for the increased species richness of the control assemblage under low nutrient-high temperature conditions. In contrast, species richness and diversity illustrated a variety of responses upon grazer removal from Zandkreek sediments.

Proulx \& Mazumder (1998) suggested that grazer effects are confounded by the trophic state, and they found that under oligotrophic conditions grazers reduced plant species richness, but under eutrophic conditions grazers increased, decreased, or did not affect species richness, depending on the study. For high nutrient treatments, species richness and diversity of B-Ham assemblages grazed by Corophium volutator were greater than the corresponding control assemblage. C. volutator grazing increased diversity under low-nutrient conditions, while species richness increased at low temperature and decreased at high temperature. Zandkreek assemblages grazed by Hydrobia ulvae did not follow a nutrient-related pattern.

\section{Corophium volutator effects}

Field and laboratory studies have shown that benthic diatoms are an important component of Corophium volutator's diet, and C. volutator feeding can significantly reduce biomass (Gerdol \& Hughes 1994b) and influence diatom species composition (Smith et al. 1996). For example, Gerdol \& Hughes (1994b) recorded significant reductions in chl $a$ and cell numbers at $C$. volutator densities as low as 9000 ind. $\mathrm{m}^{-2}$. In this study, amphipod density was equivalent to approximately 32000 ind. $\mathrm{m}^{-2}$. Significant differences in chl a and total cell densities between control and C. volutator assemblages were not found, with the exception of $\mathrm{chl} a$ concentrations for the high nutrient-high temperature treatment. However, $F_{0}{ }^{15}$ values were significantly greater for control assemblages, indicating a higher surface biomass in the absence of $C$. volutator grazing. The similarity in overall chl a concentrations between control and $C$. volutator assemblages may have occurred due to variation in the depth distribu- tion of chl a. The bioturbatory activity of $C$. volutator may prevent a stable biofilm forming at the surface by regularly redistributing chl $a$. This will influence any measure of surface biomass, such as $F_{0}{ }^{15}$, but be much less apparent in measurements of total chl $a$ unless the depth of sampling is at an extremely high resolution (Wiltshire et al. 1997, Wiltshire 2000, Kelly et al. 2001). To date, there are no studies comparing distributions of $\mathrm{chl}$ a between sediments with low and high densities of infauna.

Assemblages grazed by Corophium volutator had higher species evenness compared with control assemblages under the same environmental conditions, indicating that the dominant species were preferentially selected (Lubchenco 1978). As a generalisation, selective predation may be expected to induce higher community diversity if the preferred prey is competitively dominant (Begon et al. 1990). We infer that Nitzschia frustulum, Stauroneis sp. 1, and Navicula phyllepta were the chosen prey of $C$. volutator, since all were competitively dominant species in control assemblages, but represented only minor components of the diatom assemblages in which $C$. volutator was present. Among the environmental treatments, the structures of diatom assemblages exposed to the effects of $C$. volutator were remarkably similar. In all $4 C$. volutator assemblages, Achnanthes hauckiana and Nitzschia constricta were common, which may indicate that these 2 taxa are less susceptible to grazing. Algae such as diatoms may resist herbivory by having a large size (Lubchenco \& Gaines 1981) or conversely by being small and prostrate on the sediment surface and avoiding predation due to the morphological constraints of grazer mouthparts (Steinman et al. 1987). These results show that, at sufficiently high densities, C. volutator can regulate the assemblage composition of intertidal benthic diatoms and supersede the potential effects of the environmental conditions established in this experiment.

\section{Hydrobia ulvae effects}

Hydrobia ulvae has been shown to consume sediment microalgae (Morrisey 1988a,b, Blanchard et al. 2000, Herman et al. 2000). However, the effects of $H$. ulvae on the sediment-dwelling algae are unclear and complicated by grazing intensity and bioturbation (Levinton \& Bianchi 1981). In our study, densities of H. ulvae were high (equivalent to 75000 ind. $\mathrm{m}^{-2}$ ) but did not appear to impart a strong regulatory function on the structure of Zandkreek diatom assemblages. We suspect that this is due to negative density-dependent effects, whereby the growth rate (and therefore grazing rate) of $H$. ulvae is reduced as snail density 
increases (Morrisey 1987). Blanchard et al. (2000) reported that above a density of 25000 snails $\mathrm{m}^{-2}$ ingestion rates for individual snails declined from $26.6 \pm 1.1$ to $22.4 \pm 1.0 \mathrm{ng}$ chl a snail ${ }^{-1} \mathrm{~h}^{-1}$. A greater proportion of biomass was consumed at high temperatures, which agrees with the results of Hylleberg (1975), who found $H$. ulvae had maximal ingestion at the combination of high salinity (30) and high temperature $\left(30^{\circ} \mathrm{C}\right)$. Morrisey (1988a) suggested that a substantial fraction of microalgae grazed by $H$. ulvae was not assimilated, and in this experiment $H$. ulvae did not significantly reduce the abundance or cell density of any diatom taxa. We suspect $H$. ulvae preferred grazing subdominant species, since diversity was generally lower for grazed assemblages compared to non-grazed assemblages under the same conditions (see Swamikannu \& Hoagland 1989).

Hydrobia ulvae assemblages were weakly affected by the nutrient conditions (Fig. 3), and particularly under high nutrient conditions, the density of several taxa, including Achnanthes hauckiana, Amphora coffeaeformis var. acutiscula, Navicula gregaria and Nitzschia constricta, increased relative to control assemblages. Gastropod excreta may also have had a role to play by enriching and fertilising the diatom populations and the sediments (López-Figueroa \& Niell 1987).

\section{Environmental effects}

The composition of diatom assemblages in the absence of grazers varied in response to the environmental conditions. Species composition of control B-Ham assemblages were more strongly influenced by temperature (Fig. 1), while control Zandkreek assemblages were more strongly influenced by nutrients (Fig. 3). This indicates that adaptations of diatom taxa to the different interspecific competitive environments are potentially important when grazing pressure is minimal. High nutrient concentrations within the B-Ham sediment may have buffered the diatoms against the treatments of reduced nutrient concentrations.

Benthic algal growth is stimulated by increased temperature (see mini-review by Davison 1991) and nutrients (Posey et al. 1999), and more importantly, nutrients are hypothesized to impart a strong regulatory influence on algal dynamics (competition) and hence species composition. A major tenant of this hypothesis is that species differ in their resource requirements (taxonomic tradeoffs). Underwood \& Provot (2000) demonstrated that the form of nitrogen and salinity affected the growth rates of 4 common intertidal diatoms. Navicula phyllepta was the only taxon stud- ied by Underwood \& Provot (2000) that was also present in our study. The highest densities of $N$. phyllepta observed corresponded to the environmental optima proposed by Underwood \& Provot (2000) and therefore support their conclusion ( $N$. phyllepta optimal growth rates are between 25 and $150 \mu \mathrm{M} \mathrm{NH}_{4}, 25$ and $250 \mu \mathrm{M}$ $\mathrm{NO}_{3}$, and salinity 10 and 20). In our study, few taxa from either the B-Ham or Zandkreek assemblages showed strong responses to either nutrients or temperature (Table 2).

\section{Conclusion}

Macrofaunal species that graze on estuarine sediment populations do not simply increase or decrease species diversity of the diatoms, but can potentially do both. The precise effect depends on the relationships between food preferences, diatom competitive abilities, relative resistance to grazing, and the intensity of the grazing pressure. Within this context the dietary spectrum of the individual grazers has an important role to play and was obviously different between the grazers. Corophium volutator preferentially consumed certain dominant diatom species, while Hydrobia ulvae appeared to be a more general consumer. This is in contrast to results obtained by Morrisey (1988a), who concluded that the similar amphipod $C$. arenarium had a broader dietary range than $H$. ulvae. $C$. volutator exerted a strong regulatory influence on the species composition of benthic diatom biofilms, and it masked the potential regulatory effects of environmental conditions. This contrasted with $H$. ulvae, for which grazing effects were far less pronounced and assemblages were weakly influenced by nutrients.

Both species bioturbate the sediment, and therefore intensity of bioturbation cannot be excluded as a potentially important mechanism regulating biofilm species composition.

The estuarine milieu is by definition a harsh environment, where environmental and chemical gradients can vary steeply on both spatial and temporal scales. The lack of a nutrient and temperature response for the majority of taxa in the absence of grazers indicates that these estuarine diatom species are well adapted for a broad range of nitrogen concentrations, salinity, and temperatures.

Acknowledgements. Thanks to all members of BIOPTIS (EU MAS3-CT97-0158) and CLIMEROD (EU MAS3-CT98-0166), Jacco Kromkamp and NIOO for laboratory space and nutrient analysis, Bruno Jesus for use of the PAM, and Rich Ford for assistance. Thanks to Rupert Perkins and 4 anonymous referees for remarks, advice and comments on earlier versions of the manuscript. E.C.D. was funded by NERC grant GT/04/99/MS/269. 


\section{LITERATURE CITED}

Admiraal W (1977) Influence of various concentrations of orthophosphate on the division rate of an estuarine benthic diatom, Navicula arenaria, in culture. Mar Biol 42:1-8

Admiraal W, Peletier H, Brouwer T (1984) The seasonal succession patterns of diatom species on an intertidal mudflat: an experimental analysis. Oikos 42:30-40

Austin I, Anderson TJ, Edelvang K (1999) The influence of benthic diatoms and invertebrates on the erodibility of an intertidal mudflat, the Danish Wadden Sea. Estuar Coast Shelf Sci 49:99-111

Barranguet C, Kromkamp J (2000) Estimating primary production rates from photosynthetic electron transport in estuarine microphytobenthos. Mar Ecol Prog Ser 204: 39-54

Begon M, Harper JL, Townsend CR (1990) Ecology. Individuals, populations and communities, 2nd edn. Blackwell Scientific Publications, Oxford

Blanchard GF, Guarini JM, Provot L, Richard P, Sauriau PG (2000) Measurement of ingestion rate of Hydrobia ulvae (Pennant) on intertidal epipelic microalgae: the effect of mud snail density. J Exp Mar Biol Ecol 255:247-260

Buffan-Dubau E, Carman KR (2000) Diel feeding behaviour of meiofauna and their relationships with microalgal resources. Limnol Oceanogr 45:381-395

Cadée GC (2001) Sediment dynamics by bioturbating organisms. In: Reise K (ed) Ecological comparisons of sedimentary shores. Ecological studies, 151. Springer-Verlag, Berlin, p 127-148

Coles SM (1979) Benthic microalgal populations on intertidal sediments and their role as precursors to saltmarsh development. In: Jeffries RL, Davey AJ (eds) Ecological processes in coastal environments. Blackwell Scientific Publications, Oxford, p 25-42

Davison I (1991) Environmental effects on algal photosynthesis: temperature. J Phycol 27:2-8

Eaton JW, Moss B (1966) The estimation of numbers and pigment contents in epipelic algal populations. Limnol Oceanogr 11:584-595

Gerdol V, Hughes RG (1994a) Feeding behaviour and diet of Corophium volutator in an estuary in southeastern England. Mar Ecol Prog Ser 114:103-108

Gerdol V, Hughes RG (1994b) Effect of Corophium volutator on the abundance of benthic diatoms, bacteria and sediment stability in two estuaries of southeastern England. Mar Ecol Prog Ser 114:109-115

Herman PMJ, Middelburg JJ, Widdows J, Lucas CH, Heip CHR (2000) Stable isotopes as trophic tracers: combining field sampling and manipulative labelling of food resources for macrobenthos. Mar Ecol Prog Ser 204:79-92

Hillebrand H, Worm B, Lotze HK (2000) Marine microbenthic community structure regulated by nitrogen loading and grazing pressure. Mar Ecol Prog Ser 204:27-38

Honeywill C, Paterson DM, Hagerthey SE (2002) Instant determination of microphytobenthic biomass using fluorescence. Eur J Phycol 37:1-8

Hylleberg J (1975) The effect of salinity and temperature on egestion in mud snails (Gastropoda: Hydrobiidae). Oecologia (Berl) 21:279-289

Kelly JA, Honeywill C, Paterson DM (2001) Microscale analysis of chlorophyll $a$ in cohesive intertidal sediments: the implications of microphytobenthos distribution. J Mar Biol Assoc UK 81:151-162

Levinton JS, Bianchi TS (1981) Nutrition and food limitation of deposit feeders. I. The role of microbes in the growth of mudsnails (Hydrobiidae). J Mar Res 39:531-545
Lopez GR, Kofoed LH (1980) Epipsammic browsing and deposit-feeding in mud snails (Hydrobiidae). J Mar Res 38:585-599

López-Figueroa F, Niell FX (1987) Feeding behaviour of Hydrobia ulvae (Pennant) in microcosms. J Exp Mar Biol Ecol 114:153-167

Lubchenco J (1978) Plant species diversity in a marine intertidal community: importance of herbivore food preference and algal competitive abilities. Am Nat 112:23-39

Lubchenco J, Gaines SD (1981) A unified approach to marine plant-herbivore interactions. I. Populations and communities. Annu Rev Ecol Syst 12:405-437

MacIntyre HL, Geider RJ, Miller DC (1996) Microphytobenthos: the ecological role of the 'secret garden' of unvegetated, shallow-water marine habitats. I. Distribution, abundance, and primary production. Estuaries 19: 186-201

McClatchie S, Juniper SK, Knox GA (1982) Structure of a mud-flat diatom community in the Avon-Heathcote Estuary, New Zealand. NZ J Mar Freshw Res 16:299-309

Medlin LK (1983) Community analysis of epiphytic diatoms from selected species of macroalgae collected along the Texas coast of the Gulf of Mexico. PhD thesis, Texas A \& M University, Austin

Miller DC, Geider RJ, MacIntyre HL (1996) Microphytobenthos: the ecological role of the 'secret garden' of unvegetated, shallow-water marine habitats. II. Role in sediment stability and shallow-water food webs. Estuaries 19: $202-212$

Morrisey DJ (1987) Effect of population density and presence of a potential competitor on the growth rate of the mudsnail Hydrobia ulvae (Pennant). J Exp Mar Biol Ecol 108: 275-295

Morrisey DJ (1988a) Differences in effects of grazing by deposit-feeders Hydrobia ulvae (Pennant) (Gastropoda: Prosobranchia) and Corophium arenarium Crawford (Amphipoda) on sediment microalgal populations. I. Qualitative effects. J Exp Mar Biol Ecol 118:33-42

Morrisey DJ (1988b) Differences in effects of grazing by deposit-feeders Hydrobia ulvae (Pennant) (Gastropoda: Prosobranchia) and Corophium arenarium Crawford (Amphipoda) on sediment microalgal populations. II. Quantitative effects. J Exp Mar Biol Ecol 118:43-53

Oppenheim DR (1991) Seasonal changes in epipelic diatoms along an intertidal shore, Berrow Flats, Somerset. J Mar Biol Assoc UK 71:579-596

Page HM (1997) Importance of vascular plant and algal production to macro-invertebrate consumers in a southern California salt marsh. Estuar Coast Shelf Sci 45:823-834

Paterson DM (1997) Biological mediation of sediment erodibility: ecology and physical dynamics. In: Burt $\mathrm{N}$ et al. (eds) Cohesive sediments. John Wiley \& Sons, New York

Paterson DM, Hagerthey SE (2001) Microphytobenthos in contrasting coastal ecosystems: biology and dynamics. In: Reise K (ed) Ecological comparisons of sedimentary shores. Ecological studies, 151. Springer-Verlag, Berlin, p 105-126

Peletier H (1996) Long-term changes in intertidal estuarine diatom assemblages related to reduced input of organic waste. Mar Ecol Prog Ser 137:265-271

Perkins RG, Underwood GJC, Brotas V, Snow GC, Jesus B, Ribeiro L (2001) Responses of microphytobenthos to light: primary production and carbohydrate allocation over an emersion period. Mar Ecol Prog Ser 223:101-112

Pinckney J, Pearl HW, Fitzpatrick M (1995) Impacts of seasonality and nutrients on microbial mat community structure and function. Mar Ecol Prog Ser 123:207-216 
Posey MH, Alphin TD, Cahoon L, Lindquist D, Becker ME (1999) Interactive effects of nutrient additions and predation on infaunal communities. Estuaries 22:785-792

Power ME (1992) Top-down and bottom-up forces in food webs: do plants have primacy? Ecology 73:733-746

Proulx M, Mazumder A (1998) Reversal of grazing impact on plant species richness in nutrient-poor vs. nutrient-rich ecosystems. Ecology 79:2581-2592

Reise K (1992) Grazing on sediment shores. In: John DM, Hawkins SJ, Price JH (eds) Plant-animal interactions in the marine benthos. Systematics Association Spec Vol 46. Clarendon Press, Oxford, p 133-145

Saburova MA, Polikarpov IG, Burkovsky IV (1995) Spatial structure of an intertidal sandflat microphytobenthos community as related to different spatial scales. Mar Ecol Prog Ser 129:229-239

Smith D, Hughes RG, Cox EJ (1996) Predation of epipelic diatoms by the amphipod Corophium volutator and the polychaete Nereis diversicolor. Mar Ecol Prog Ser 145:53-61

Steinman AD (1991) Effects of herbivore size and hunger level on periphyton communities. J Phycol 27:54-59

Steinman AD, McIntire CD, Gregory SV, Lamberti GA, Ashkenas LR (1987) Effects of herbivore type and density on taxonomic structure and physiognomy of algal assemblages in laboratory streams. J N Am Benthol Soc 6: 189-197

Swamikannu X, Hoagland KD (1989) Effects of snail grazing on the diversity and structure of a periphyton community in a eutrophic pond. Can J Fish Aquat Sci 46:1698-1704

Tilman D (1999) The ecological consequences of changes in biodiversity. A search for general principles. Ecology 80: 1455-1474

Underwood GJC (1994) Seasonal and spatial variation in epipelic diatom assemblages in the Severn Estuary. Diatom Res 9:451-472

Underwood GJC (1997) Microalgal colonisation in a saltmarsh restoration scheme. Estuar Coast Shelf Sci 44:471-481

Editorial responsibility: Otto Kinne (Editor),

Oldendorf/Luhe, Germany
Underwood GJC, Kromkamp J (1999) Primary production by phytoplankton and microphytobenthos in estuaries. In: Nedwell DB, Raffaelli DG (eds) Advances in ecological research: estuaries. Academic Press, New York

Underwood GJC, Paterson DM (1993) Recovery of intertidal benthic diatoms after biocide treatment and associated sediment dynamics. J Mar Biol Assoc UK 73:25-45

Underwood GJC, Provot L (2000) Determining the environmental preferences of four estuarine epipelic diatom taxa: growth across a range of salinity, nitrate, and ammonium conditions. Eur J Phycol 35:173-182

Underwood GJC, Phillips J, Saunders K (1998) Distribution of estuarine benthic diatom species along salinity and nutrient gradients. Eur J Phycol 33:173-183

Wiltshire KH (2000) Algae and associated pigments of intertidal sediments; new observations and methods. Limnologica 30:205-214

Wiltshire KH, Blackburn J, Paterson DM (1997) The Cryolander, a new method for fine-scale in situ sampling of intertidal surface sediments. J Sediment Res 97:977-981

Wiltshire KH, Tolhurst T, Paterson DM, Davidson I, Gust G (1998) Pigment fingerprints as markers of erosion. In: Black KS, Paterson DM, Cramp A (eds) Sedimentary processes in the intertidal zone. Geol Soc Lond Spec Publ 139: 99-114

Wulff A, Wängberg S, Sunbäck K, Nilsson C, Underwood GJC (2000) Effects of UVB radiation on a marine microphytobenthic community growing on a sand-substratum under different nutrient conditions. Limnol Oceanogr 45: $1144-1152$

Yallop ML, de Winder B, Paterson DM, Stal LJ (1994) Comparative structure, primary production and biogenic stabilisation of cohesive and non-cohesive marine sediments inhabited by microphytobenthos. Estuar Coast Shelf Sci 39:565-582

Zar JH (1999) Biostatistical analysis, 4th edn. Prentice Hall, Englewood Cliffs, NJ

Submitted: April 16, 2002; Accepted: October 15, 2002

Proofs received from author(s): December 10, 2002 